\title{
Pertumbuhan dan Produksi Tomat (Lycopersicon esculentum Mill.) Varietas Servo pada Frekuensi Penyiraman yang Berbeda
}

\section{Growth and Fruit Production of Tomato Servo Variety (Lycopersicon esculentum Mill.) at the Different Watering Frequency}

\author{
Sulistyowati, Yulita Nurchayati*, Nintya Setiari \\ Program Studi Biologi, Fakultas Sains dan Matematika, Universitas Diponegoro, Semarang \\ *Email : yulita.yoko@gmail.com
}

Diterima 30 Desember 2020 / Disetujui 3 Maret 2021

\begin{abstract}
ABSTRAK
Tomat merupakan tanaman familia Solanaceae yang memiliki nilai ekonomis. Penyediaan air yang cukup selama budidaya mempengaruhi pertumbuhan dan produksi buah tomat. Tujuan penelitian ini untuk mengetahui pengaruh frekuensi penyiraman terhadap pertumbuhan dan produksi buah tomat. Penelitian dilakukan di rumah percobaan dan Laboratorium Biologi Struktur dan Fungsi Tumbuhan Departemen Biologi FSM UNDIP. Desain penelitian dilakukan dengan menggunakan Rancangan Acak Lengkap (RAL) yang terdiri dari tiga perlakuan yaitu frekuensi penyiraman setiap hari, frekuensi penyiraman dua hari sekali, dan frekuensi penyiraman tiga hari sekali. Percobaan dilakukan dengan lima ulangan. Data dianalisis menggunakan analisis varians (ANOVA) pada taraf kepercayaan 95\% dan dilanjutkan dengan uji Duncan. Hasil penelitian menunjukkan bahwa frekuensi penyiraman berpengaruh terhadap tinggi tanaman, bobot segar tanaman, waktu muncul bunga, jumlah buah, berat buah dan kandungan karotenoid buah tomat. Semakin sering frekuensi penyiraman dapat meningkatkan pertumbuhan dan produksi buah tetapi semakin berkurang frekuensi penyiraman maka berdampak pada kandungan karotenoid buahnya.
\end{abstract}

Kata kunci : karotenoid, varietas, cekaman kekeringan

\begin{abstract}
Tomato is plant that belong to the family Solanaceae. Availability of sufficient water during cultivation affects the growth and production of tomatoes. The purpose of this study was to determine the effect of watering frequency on the growth and production of tomatoes fruit. The research was conducted in the experimental house and the Laboratory of Plant Structure and Function Biology, Department of Biology, Faculty of Mathematics and Sciences, Diponegoro University. The research design was using completely randomized design with three treatments consists of everyday frequency watering, once two days, and once three days. The treatment conduct with five replications. Data were analyzed using analysis of variance (ANOVA) and Duncan test. The results showed that frequency watering treatment had a significantly effects on plant height, plant weight, flower initiation, number of fruits per plant, fruit weight, and carotenoid contents. Sufficient of water frequency can increase growth and tomatoes production but decrease of watering frequency can increase carotenoid contents.
\end{abstract}

Keywords : carotenoid, variety, water stress 


\section{PENDAHULUAN}

Tomat (Lycopersicon esculentum Mill.) merupakan salah satu komoditas hortikultura yang mempunyai nilai ekonomis tinggi. Tanaman tomat mudah dibudidayakan karena memiliki daya adaptasi tinggi dan umur yang relatif pendek. Data dari Badan Pusat Statistik dan Direktorat Jenderal Hortikultura (2019) menunjukkan bahwa produksi tomat di Indonesia pada tahun 2016 sebanyak 883.233 ton per tahun, sedangkan tahun 2017 meningkat menjadi 962.825 ton per tahun. Tomat varietas Servo merupakan salah satu jenis tomat sayur yang beradaptasi dengan baik di dataran rendah. Buahnya keras dengan rasa manis dan sedikit asam, namun tomat ini tahan terhadap Geminivirus (Kementerian Pertanian, 2013).

Upaya pengembangan agribisnis tanaman tomat antara lain adalah dengan penyediaan air yang mencukupi selama proses budidaya. Air merupakan komponen penting bagi keberlangsungan berbagai proses fisiologi tanaman yaitu dalam penyerapan unsur hara dan faktor penting dalam fotosintesis. Oleh karena itu, kekurangan air dapat menghambat pertumbuhan dan menurunkan produktivitas tanaman. Kurangnya ketersediaan air pada budidaya tanaman mengakibatkan tanaman mengalami cekaman kekeringan. Hal tersebut karena kurangnya ketersediaan air mengakibatkan hara yang diserap tanaman terbatas sehingga pertumbuhan tanaman terhambat (Jumawati dkk. 2014; Kusumastuti dan Ardiyanta, 2019).

Cekaman kekeringan adalah kondisi rendahnya ketersediaan air tanah yang dapat menyebabkan stres pada tanaman, sehingga menurunkan pertumbuhan dan perkembangan tanaman. Cekaman tersebut dapat membatasi produktivitas tanaman dengan memengaruhi berbagai perubahan morfologis, fisiologis, dan molekuler pada tanaman yang berakibat pada menurunnya kualitas produksi tanaman (Petrovic et al, 2019), juga nilai gizi buah termasuk kandungan karoteniodnya (Caldana et al. 2011; Ramakrishna dan Ravishankar, 2011).

Salah satu cara untuk mengetahui bentuk cekaman kekeringan pada tanaman adalah dengan pemberian perlakuan frekuensi penyiraman.
Jumawati dkk. (2014) menyatakan tanaman tomat yang diberi cekaman kekeringan dapat mempengaruhi produksi senyawa metabolitnya, namun frekuensi penyiraman yang semakin jarang dapat menurunkan pertumbuhan tomat. Kusumastuti dan Ardiyanta (2019) menyatakan frekuensi penyiraman 2 hari sekali memberikan hasil pertumbuhan terbaik pada tomat varietas Betavila. Penelitian ini mengkaji mengenai pengaruh frekuensi penyiraman terhadap pertumbuhan dan produksi buah tomat varietas Servo.

\section{METODE PENELITIAN}

Penelitian dilakukan di Rumah Percobaan dan Laboratorium Biologi Struktur dan Fungsi Tumbuhan, Fakultas Sains dan Matematika, Universitas Diponegoro, Semarang. Penelitian dilaksanakan pada bulan Januari-Mei 2020. Tanaman tomat yang digunakan sebagai bahan baku penelitian adalah bibit tomat varietas F1 Servo. Benih tomat F1 Servo disemai dalam polybag dengan masing-masing polybag diisi 2 benih tomat. Benih disiram setiap pagi dan sore menggunakan sprayer. Bibit yang berumur 4 minggu kemudian dipindah tanam menggunakan polybag ukuran $40 \times 40 \mathrm{~cm}$. Masing-masing polybag berisi satu bibit tanaman tomat.

\section{Penentuan Volume Penyiraman Kapasitas Lapang}

Penentuan volume penyiraman kapasitas lapang dilakukan berdasarkan metode Hendriyani dan Setiari (2009) dengan modifikasi. Penentuan kapasitas lapang dilakukan untuk mengetahui volume penyiraman. Penentuan kapasitas lapang dilakukan dengan mengisi polybag ukuran $15 \times 15 \mathrm{~cm}$ dengan media tanam akan yang digunakan, masing-masing polybag diisi media tanam sebanyak $400 \mathrm{~g}$. Semua polybag disiram dengan air sampai keadaan jenuh kemudian dibiarkan selama 24 jam sampai air tidak menetes lagi, selanjutnya ditimbang sebagai berat basah (Tb). Media tanam dimasukkan ke dalam oven pada suhu $50^{\circ} \mathrm{C}$ selama 3 hari sampai diperoleh berat konstan. Hasil pengeringan ditimbang untuk memperoleh nilai berat kering (Tk). Percobaan 
dilakukan dengan 5 ulangan, kemudian dihitung kapasitas lapang tanah menggunakan rumus sebagai berikut:

$\mathrm{KL}=\frac{(T b-T k)}{T k} \times 100 \%$

Keterangan :

$\mathrm{KL}=$ Kapasitas lapang;

$\mathrm{Tb}=$ Berat basah;

$\mathrm{Tk}=$ Berat kering

\section{Penanaman dan Perlakuan}

Bibit tanaman tomat yang berumur 4 minggu dipindah ke dalam polybag ukuran 40x40cm. Perlakuan frekuensi penyiraman dilakukan pada bibit umur 4 minggu setelah semai (MSS) hingga umur 65 hari setelah tanam (HST), dengan volume penyiraman sebanyak $575 \mathrm{~mL}$. Tanaman tomat yang telah berumur 65 HST dipanen dan dipisahkan antara buah dan tangkainya. Buah tomat kemudian diekstrak dengan cara dihaluskan menggunakan mortar yang kemudian digunakan untuk bahan analisis kandungan karotenoid.

\section{Analisis Kandungan Karotenoid}

Analisis kandungan karotenoid dilakukan dengan metode spektrofotometri menggunakan spektrofotometer UV-Vis. Buah tomat sebanyak $0,1 \mathrm{~g}$ digerus dengan mortar. Buah yang sudah digerus kemudian diekstraksi dengan $10 \mathrm{~mL}$ aseton $80 \%$. Ekstrak kemudian disaring menggunakan kertas saring. Filtrat kemudian dimasukkan dalam kuvet dan diukur kandungan karotenoidnya pada panjang gelombang $480 \mathrm{~nm}$, $645 \mathrm{~nm}$, dan $663 \mathrm{~nm}$. Penghitungan karotenoid total ditentukan berdasarkan nilai absorbansi dalam rumus sebagai berikut:

Karotenoid $(\mu \mathrm{mol} / \mathrm{g}): \underline{(\mathrm{A} 480+0,114 \times \mathrm{A} 663-0,638 \times \mathrm{A} 645) \times \mathrm{V} \times 10^{3}}$

\section{$112,5 \times \mathrm{W}$}

Keterangan :

A480 = Absorbansi pada panjang gelombang A480 nm; $\mathrm{A} 663$ = Absorbansi pada panjang gelombang A663 nm; A645 = Absorbansi pada panjang gelombang A645 nm; V = Volume ekstrak (mL); W = berat sampel (g). (Hendry dan Grime, 1993)

\section{Analisis Data}

Penelitian ini dilakukan dengan menggunakan Rancangan Acak Lengkap (RAL) dan terdiri dari tiga perlakuan penyiraman yaitu setiap hari, 2 hari sekali, dan 3 hari sekali. Penelitian dilakukan dengan 5 ulangan. Data dianalisis secara statistik dengan menggunakan Analysis of Variance (ANOVA) pada taraf kepercayaan 95\%. Jika terdapat beda nyata dilakukan uji lanjut dengan menggunakan Uji DMRT (Duncan's Multiple Range Test).

\section{HASIL DAN PEMBAHASAN}

\section{Tinggi Tanaman dan Bobot Segar Tanaman}

Hasil ANOVA menunjukkan bahwa frekuensi penyiraman berpengaruh terhadap tinggi tanaman dan bobot segar tanaman. Tabel 1 menunjukkan bahwa frekuensi penyiraman setiap hari menghasilkan tanaman tertinggi dan memiliki bobot segar yang tinggi, berbeda nyata dengan perlakuan frekuensi penyiraman dua hari sekali dan tiga hari sekali. Hal tersebut karena pada perlakuan frekuensi penyiraman setiap hari tanaman memiliki ketersediaan air yang cukup untuk melangsungkan pertumbuhan dan perkembangan. Sementara tanaman pada perlakuan frekuensi penyiraman dua hari dan tiga hari sekali ketersediaan airnya mulai berkurang. Apabila ketersediaan air berkurang maka nutrisi yang diserap tanaman terbatas, proses fotosintesis pada tanaman juga terhambat sehingga energi dan cadangan makanan untuk pertumbuhan berkurang. Air bagi tanaman berperan sebagai pelarut senyawa organik, menjaga turgor sel, dan membantu metabolisme terutama proses fotosintesis. Menurut Jumawati dkk. (2014), frekuensi penyiraman yang berkurang dapat menyebabkan penurunan tinggi tanaman. Tanaman yang memiliki suplai air yang cukup menghasilkan tinggi tanaman paling tinggi dibandingkan yang kekurangan air. 
Tabel 1. Rerata tinggi tanaman $(\mathrm{cm})$ dan bobot segar tanaman $(\mathrm{g})$ tomat Servo pada umur 65 HST

\begin{tabular}{ccc}
\hline Frekuensi Penyiraman & Tinggi tanaman $(\mathbf{c m})$ & Bobot segar tanaman $(\mathbf{g})$ \\
\hline Setiap hari & $131,06 \pm 8,47^{\mathrm{a}}$ & $214,66 \pm 7,98^{\mathrm{a}}$ \\
Dua hari sekali & $111,84 \pm 5,66^{\mathrm{b}}$ & $192,62 \pm 9,08^{\mathrm{a}}$ \\
Tiga hari sekali & $116,76 \pm 7,54^{\mathrm{b}}$ & $184,12 \pm 7,49^{\mathrm{b}}$ \\
\hline
\end{tabular}

Keterangan: Angka yang diikuti oleh huruf yang tidak sama menunjukkan hasil yang berbeda nyata pada uji Duncan taraf kepercayaan 95\%.

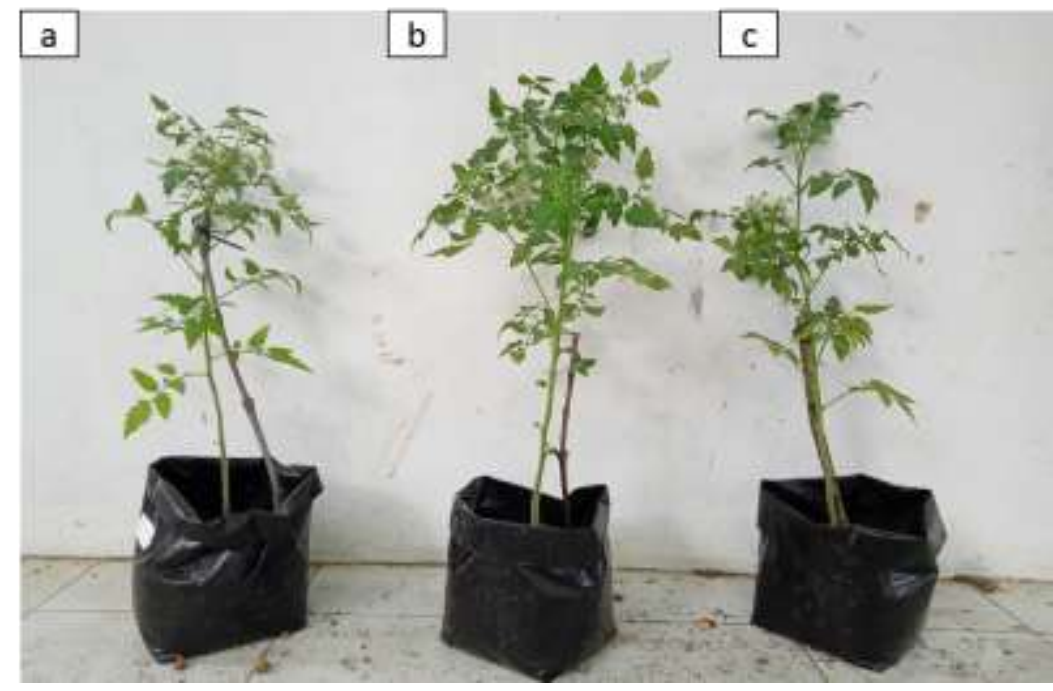

Gambar 1. Tanaman tomat umur 40 HST (a) Frekuensi penyiraman setiap hari; (b) Frekuensi penyiraman dua hari sekali; (c) Frekuensi penyiraman tiga hari sekali



Gambar 2. Pertumbuhan tanaman tomat umur 60 HST (a) Frekuensi penyiraman setiap hari; (b) Frekuensi penyiraman dua hari sekali; (c) Frekuensi penyiraman tiga hari sekali

Proses pertumbuhan tinggi tanaman diawali dengan proses pembelahan dan pembesaran sel untuk membentuk tunas. Proses tersebut dipengaruhi oleh turgor sel, pembelahan dan pembesaran sel akan terjadi apabila sel mengalami turgiditas yang faktor utamanya adalah air. Penurunan turgiditas dapat mengakibatkan pertumbuhan tinggi tanaman 
terhambat dan tanaman menjadi kerdil (Samanhudi, 2010).

Penurunan bobot segar tanaman diduga karena rendahnya laju fotosintesis akibat berkurangnya asimilasi $\mathrm{CO}_{2}$ oleh tanaman. Menurut Toscano et al. (2019), ketersediaan air yang rendah mengakibatkan penurunan pertumbuhan vegetatif dan produksi tanaman dengan cara mengurangi pertumbuhan organ daun atau buah. Penelitian yang dilakukan oleh Marsha dkk. (2014), menunjukkan bahwa pemberian frekuensi penyiraman tiga hari sekali dengan volume air $75 \%$ kapasitas lapang memberikan pertumbuhan efisien terhadap tinggi tanaman, jumlah daun dan panjang akar pada tanaman Crotalaria mucronata. Hendrata dan Sutardi (2010), menyatakan bahwa frekuensi penyiraman 3 hari sekali pada bibit kakao menghasilkan pertumbuhan tanaman yang terbaik.
Pertumbuhan tomat Servo pada perlakuan frekuensi penyiraman dapat dilihat pada Gambar 1 dan Gambar 2. Tanaman yang mendapat perlakuan penyiraman setiap hari menghasilkan buah yang lebih banyak dan memiliki pertumbuhan paling tinggi dibandingkan perlakuan frekuensi penyiraman dua hari dan tiga hari sekali.

\section{Waktu Muncul Bunga}

Waktu munculnya bunga merupakan fase yang ditandai dengan berakhirnya fase vegetatif tanaman dan dimulainya fase generatif. Menurut Fauzi dkk. (2017) pembungaan merupakan bagian penting dalam kegiatan produksi tanaman. Induksi pertumbuhan dan perkembangan tajuk ditentukan oleh faktor yang menyebabkan suatu perubahan jenis tajuk menjadi tajuk vegetatif atau menjadi tajuk generatif. Terjadinya induksi pembungaan disebabkan karena adanya rangsangan induksi oleh florigenic promoter (FP).

Tabel 2. Waktu muncul bunga tomat (HST) pada perlakuan penyiraman yang berbeda

\begin{tabular}{cc}
\hline Frekuensi Penyiraman & Rata-rata \\
\hline Setiap hari & $23,80 \pm 0,83^{\mathrm{a}}$ \\
Dua hari sekali & $25,20 \pm 0,83^{\mathrm{b}}$ \\
Tiga hari sekali & $25,00 \pm 0,70^{\mathrm{b}}$ \\
\hline
\end{tabular}

Keterangan: Angka yang diikuti oleh huruf yang tidak sama menunjukkan hasil yang berbeda nyata pada uji Duncan taraf kepercayaan $95 \%$.

Hasil ANOVA menunjukkan bahwa frekuensi penyiraman berpengaruh terhadap waktu muncul bunga (Tabel 2). Penyediaan air di sini berperan dalam pembentukan tunas pada tanaman. Suplai air yang cukup menyebabkan tanaman dapat melangsungkan proses pembelahan dan pembesaran sel. Hal tersebut sesuai dengan Ramirez dan Davenport (2010) bahwa dalam pertumbuhan tanaman terdapat dua tahap penting yaitu inisiasi dan induksi. Tahap inisiasi merupakan tahap awal pembentukan tunas, pada tahap ini terjadi pembelahan dan pembesaran karena masuknya air ke dalam sel. Selanjutnya tahap induksi, tahap ini menentukan pertumbuhan tunas menjadi tunas vegetatif atau generatif. Kurangnya ketersediaan air dapat menghambat pembentukan tunas vegetatif maupun tunas generatif pada tanaman sehingga pertumbuhan dan inisiasi pembungaan pada tanaman menjadi lebih lambat.
Selain ketersediaan air, pembungaan juga dipengaruhi oleh keseimbangan hormon endogen. Salah satunya adalah giberelin yang disintesis seiring bertambahnya umur tajuk tanaman, dan pengaruh hormon sitokinin yang berperan dalam memecah masa dormansi tunas. Menurut Fauzi dkk. (2017), giberelin merupakan salah satu hormon yang berperan dalam pembungaan. Konsentrasi giberelin akan meningkat seiring bertambahnya umur tanaman. Konsentrasi hormon tersebut tertinggi terjadi saat diferensiasi daun dan terjadi penurunan pada saat masa istirahat pada tajuk dan saat munculnya bunga. Hormon sitokinin juga berpengaruh dalam pembungaan. Sitokinin merupakan hormon yang berperan dalam pembelahan sel dan mampu memecah masa dormansi tunas. Pecahnya masa dormansi tunas pada kondisi lingkungan yang cocok dapat menyebabkan inisiasi pembungaan 


\section{Jumlah Buah dan Berat Total Buah}

Salah satu parameter untuk mengetahui produksi tanaman adalah dengan mengetahui jumlah buah dan berat buah yang dihasilkan. Produksi buah ditentukan dengan cara menghitung dan menimbang buah pada saat panen. Hal tersebut diduga karena semakin jarang pemberian penyiraman pada tanaman mengakibatkan terbatasnya hara dan mineral yang diserap sehingga metabolisme tanaman untuk melangsungkan perkembangan dan pembentukan buah terhambat. Frekuensi penyiraman tidak hanya mempengaruhi jumlah buah tetapi juga berat buahnya, karena pada saat pembentukan buah terjadi penimbunan cadangan makanan hasil fotosintesis. Berkurangnya aktivitas fotosintesis maka energi dan fotosintat yang dihasilkan tanaman untuk pekembangan dan pembentukan buah menjadi berkurang.

Tabel 3. Rerata jumlah buah dan berat total buah tomat (g) pada perlakuan penyiraman yang berbeda

\begin{tabular}{ccc}
\hline Frekuensi Penyiraman & Jumlah buah & Berat total buah $(\mathbf{g})$ \\
\hline Setiap hari & $25,20 \pm 1,78^{\mathrm{a}}$ & $419,54 \pm 6,82^{\mathrm{a}}$ \\
Dua hari sekali & $18,40 \pm 1,14^{\mathrm{b}}$ & $305,37 \pm 15,92^{\mathrm{b}}$ \\
Tiga hari sekali & $13,80 \pm 1,30^{\mathrm{c}}$ & $191,43 \pm 12,98^{\mathrm{c}}$ \\
\hline
\end{tabular}

Keterangan: Angka yang diikuti oleh huruf yang tidak sama menunjukkan hasil yang berbeda nyata pada uji Duncan taraf kepercayaan $95 \%$.

Penyiraman yang kurang pada tanaman menyebabkan ketersediaan air untuk mendukung metabolisme tanaman menurun sehingga pertumbuhan dan perkembangan tanaman juga terhambat. menyatakan penurunan aktivitas fotosintesis dan respirasi menyebabkan energi yang dibutuhkan untuk pertumbuhan menurun sehingga proses pembelahan dan pembentangan sel untuk memperbesar organ juga menurun. Akibatnya organ tumbuhan yang terbentuk menjadi lebih kecil dan produksi yang dihasilkan juga semakin sedikit (Dzajuli, 2010; Pratiwi, 2011).

\section{Kandungan Karotenoid}

Karotenoid merupakan pigmen yang dominan pada buah tomat. Penentuan kandungan karotenoid buah ini dapat digunakan untuk mengetahui salah satu kandungan nutrisi buah tomat dalam kondisi cekaman lingkungan. Karotenoid umumnya dijumpai terakumulasi pada jaringan atau organ penimbun sebagai cadangan makanan seperti buah tomat (Kurniawan dkk. 2010)

Tabel 4. Kandungan karotenoid buah tomat $(\mu \mathrm{mol} / \mathrm{g})$ pada perlakuan penyiraman yang berbeda

\begin{tabular}{cc}
\hline Frekuensi Penyiraman & Rata-rata \\
\hline Setiap hari & $2,13 \pm 0,69^{\mathrm{c}}$ \\
Dua hari sekali & $2,41 \pm 0,08^{\mathrm{b}}$ \\
Tiga hari sekali & $3,29 \pm 0,12^{\mathrm{a}}$ \\
\hline
\end{tabular}

Keterangan: Angka yang diikuti oleh huruf yang tidak sama menunjukkan hasil yang berbeda nyata pada uji Duncan taraf kepercayaan $95 \%$.

Hasil ANOVA menunjukkan bahwa frekuensi penyiraman berpengaruh terhadap kandungan karotenoid buah tomat (Tabel 5). Hal tersebut diduga karena semakin jarang frekuensi penyiraman yang diberikan maka tanaman mengalami cekaman sehingga merangsang pembentukan senyawa antioksidan. Cekaman kekeringan dapat mengakibatkan stres oksidatif pada tanaman akibat ketidakseimbangan produksi senyawa reactive oxigen species (ROS) dalam sel. Peningkatan senyawa ROS dalam sel dapat menyebabkan terjadinya oksidasi protein, peroksidasi membran lipid dan peningkatan fotorespirasi. Tanaman mencegah terjadinya stres 
oksidatif dengan menbentuk senyawa pertahanan metabolit sekunder seperti karotenoid. Hal tersebut sesuai dengan pernyataan Sharma dan Zheng (2019) bahwa tanaman yang mengalami cekaman membentuk sistem pertahanan dengan menghasilkan senyawa antioksidan untuk mengatur proses biologi di bawah kondisi lingkungan yang kurang menguntungkan. Senyawa antioksidan ini terdiri atas sistem enzimatik dan non-enzimatik yang bekerja untuk mengontrol tingkat senyawa ROS dalam sel. Fanciulino et al. (2013), menyatakan bahwa dalam kondisi lingkungan yang kurang menguntungkan tanaman melakukan adaptasi. Cekaman lingkungan abiotik dan biotik menyebabkan stres oksidatif pada tanaman sehingga sinyal pengatur stres oksidatif mensintesis dan mengakumulasikan senyawa metabolit sekunder termasuk karotenoid yang berperan sebagai senyawa antioksidan.

Peningkatan kandungan karotenoid ini diduga karena adanya peningkatan biosintesis hormon asam absisat (ABA) selama fase kekurangan air tersebut. Senyawa zeaxanthin yang dihasilkan dari jalur biosintesis karotenoid akan digunakan dalam proses biosintesis ABA. ABA merupakan hormon yang diproduksi tanaman yang mengatur pembukaan stomata ketika mengalami cekaman air. Peningkatan jumlah karotenoid pada buah diikuti oleh peningkatan jumlah ABA pada tanaman yang dapat merangsang penutupan stomata (Sharma dan Zheng, 2019; Norshazila et al. 2017; Osakabe et al. 2014).

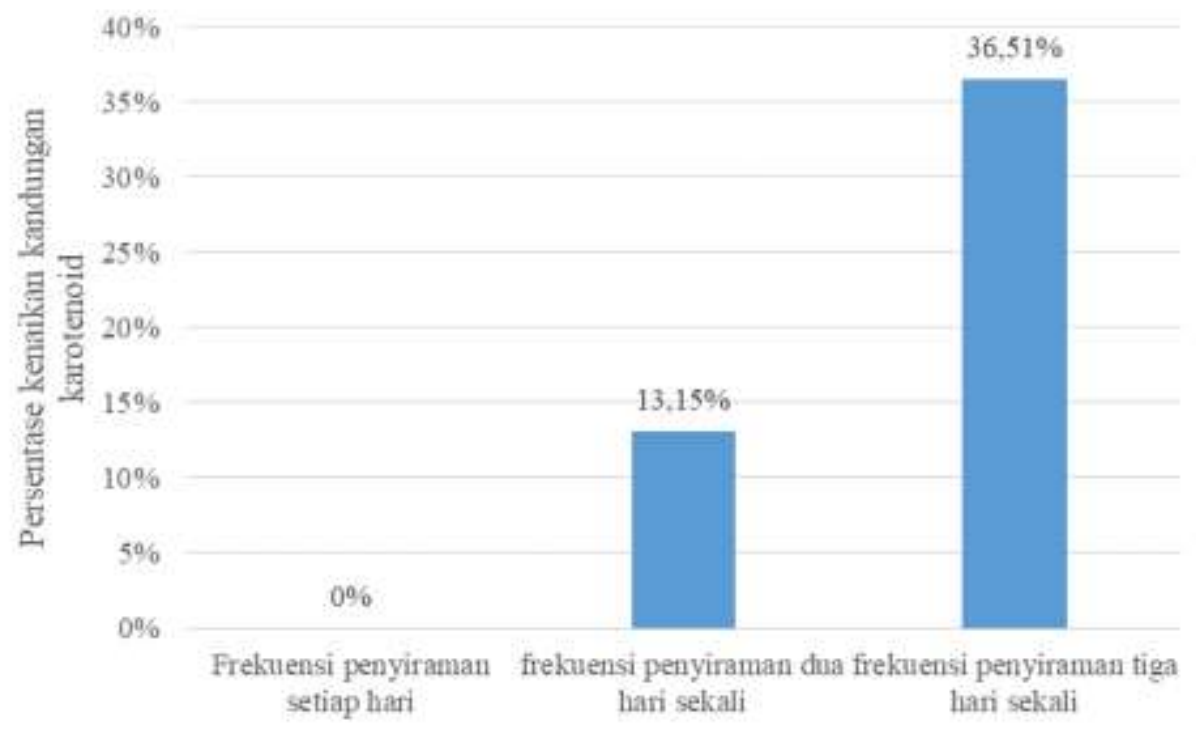

Gambar 3. Persentase kenaikan kandungan karotenoid buah tomat Servo pada frekuensi penyiraman yang berbeda

Persentase kenaikan kandungan karotenoid buah tomat Servo pada masing-masing perlakuan penyiraman ditunjukkan pada Gambar 3. Kenaikan kandungan karotenoid dari frekuensi penyiraman setiap hari dan dua hari sekali adalah $13,15 \%$, sedangkan kenaikan kandungan karotenoid dari frekuensi penyiraman dua hari sekali dan tiga hari sekali adalah $36,51 \%$. Artinya frekuensi penyiraman tiga hari sekali dapat digunakan untuk produksi buah tomat dengan kandungan karotenoid tinggi. Berkurangnya ketersediaan air menyebabkan tanaman menghasilkan senyawa karotenoid yang berfungsi sebagai antioksidan untuk mempertahankan diri pada kondisi cekaman. Menurut Gutzeit dan Ludwig-Muller (2014) karotenoid merupakan salah satu jenis metabolit sekunder yang dihasilkan oleh tanaman pada kondisi cekaman biotik dan abiotik. Fanciulino et al. (2014), menyatakan bahwa beberapa senyawa produk 
dari karotenoid seperti $\mathrm{ABA}$, strigolaktons, dan b-cyclocitral berperan penting dalam merespon perubahan lingkungan. Senyawa tersebut juga berperan dalam regulasi biosintesis karotenoid, seperti proses pembentukan ABA yang terbentuk melalui degradasi xantophil, violaxanthin atau neoxanthin yang akan meningkat ketika terjadi cekaman lingkungan seperti cekaman kekeringan dan salinitas.

\section{KESIMPULAN}

Frekuensi penyiraman berpengaruh terhadap tinggi tanaman, bobot segaar tanaman, waktu muncul bunga, jumlah buah, berat buah dan kandungan karotenoid buah tomat Servo. Semakin sering frekuensi penyiraman dapat meningkatkan pertumbuhan dan produksi buah, tetapi semakin berkurang frekuensi penyiraman maka berdampak pada peningkatan kandungan karotenoid buahnya.

\section{UCAPAN TERIMA KASIH}

Kami ucapkan terima kasih kepada Lembaga Penelitian dan Pengabdian Kepada Masyarakat Universitas Diponegoro atas dukungan dana penelitian melalui Riset Penerapan dan Pengembangan (RPP) tahun 2020 Nomor : 329-54/UN7.6.1/PP/2020.

\section{DAFTAR PUSTAKA}

Caldana, C., T. Degenkolbe, A. CuadrosInostroza, S. Klie, R. Sulpice, A. Leisse, D. Steinhauser, A.R. Fernie, L. Willmitzer, dan M.A. Hannah. 2011. High-Density Kinetic Analysis of The Metabolomic and Transcriptomic Response of Arabidopsis to Eight Environmental Conditions. Plant J. 67 (5): 869-884.

Gutzeit, H.O., dan J. Ludwig-Muller. 2014. Plant Natural Products: Synthesis, Biological Functions and Practical Applications. New York: Wiley-VCH GmbH and Co.

Djazuli, M. 2010. Pengaruh Cekaman Kekeringan Terhadap Pertumbuhan dan
Beberapa Karakter Morfo-Fisiologis Tanaman Nilam. Bul. Littro 21 (1): 8-17.

Fanciulino, A.I., I.P.R. Bidel, dan I. Urban. 2014. Carotenoid Response to Environmental Stimuli: Integrating Redox and Carbon Controls into a Fruit Model. Plant Cell and Environment. 37: 273-289.

Fauzi, A.A., W. Sutari, Nursuhud, dan S. Mubarok. 2017. Faktor yang Mempengaruhi Pembungaan pada Mangga (Mangifera indica L.). Jurnal Kultivasi. 16 (3):461-465.

Hendrata, R., dan Sutardi. 2010. Evaluasi Media dan Frekuensi Penyiraman terhadap Pertumbuhan Bibit Kakao (Theobroma cacao L.). Agrovigor. 3 (1) : 10-18.

Hendry, G. A. F., dan Grime, J.P., 1993. Methods on Comparative Plant Ecology A Laboratory Manual. London: Chapman and Hill.

Hendriyani I.S., dan N. Setiari. 2009. Kandungan Klorofil dan Pertumbuhan Kacang Panjang (Vigna sinensis) pada Tingkat Penyediaan Air yang Berbeda. J Sains Mat. 17:145150.

Jumawati, R., A.T. Sakya., dan M. Rahayu. 2014. Pertumbuhan Tomat pada Frekuensi Pengairan yang Berbeda. Agrosains. Vol. 16 (1): 13-18.

Kurniawan, M., M. Izzati, dan Y. Nurchayati. 2010. Kandungan Klorofil, Karotenoid, dan Vitamin C pada Beberapa Spesies Tumbuhan Akuatik. Buletin Anatomi dan Fisiologi. 18(1): 28-40.

Kusumastuti, C.T., dan Ardiyanta. 2019. Respon Pertumbuhan dan Kualitas Hasil Beberapa Varietas Tomat pada Berbagai Frekuensi Penyiraman. Savana Cendana. 4 (1): 1-2.

Marsha, N.D., N. Aini, dan T. Sumarni. 2014. Pengaruh Frekuensi dan Volume Pemberian Air pada Pertumbuhan Tanaman Crotalaria mucronata Desv. Jurnal Produksi Tanaman. 2 (8): 673-678

Norshazila, S., R. Othman, I. Jaswir, dan H.H.Z. Yumi. 2017. Effect of Abiotic Stress on 
Carotenoid Accumulation in Pumpkin Plants Under Light and Dark Condition. Food Research Journal. 24: 387-394.

Osakabe, Y., K. Osakabe, K. Shinozaki, L.P.

Tran. 2014. Respon of Plant to Water

Stress. Frontiers Plant Science. 5 (86): 1-8.

Petrovic, I., S. Savic, Z. Jovanovic, R. Stikic, B., Brunel, S., Serino, dan N. Bertin. 2019. Fruit Quality of Cherry and Large Fruited Tomato Genotypes as Influenced by Water Deficit. Agriculture. 106 (2): 123-128.

Pratiwi, H. 2011. Pengaruh Kekeringan pada Berbagai Fase Tumbuh Kacang Tanah. Buletin Palawija. 22: 71-78.

Ramakrishna, A. dan G. A. Ravishankar. 2011. Influence of Abiotic Stress Signals on Secondary Metabolites in Plants. Plant Signaling and Behavior. 6: (11): 17201731.

Ramirez, F., dan T.L. Davenport. 2010. Mango (Mangifera indica L.) Flowering Physiology. Science Horticultura. 126: 6572.

Republik Indonesia, Lampiran Surat Keputusan Menteri Pertanian. Nomor: 093/Kpts/SR.120/D.2.7/9/2013 tentang Deskripsi Tomat Hibrida (F1) Varietas Servo.

Samanhudi, 2010. Pengujian Cepat Ketahanan Tanaman Sorgum Manis terhadap Cekaman Kekeringan. Agrosains. 12(1): 9-13.

Sharma, A., dan B. Zheng. 2019. Melatonin Mediated Regulation of Drought Stress: Physiological and Molecular Aspects. Plants. 8: 1-17.

Toscano S., A. Trivellini, G. Cocetta, R. Bulgari, A. Francini, D. Romano dan A. Ferrante. 2019. Effect of Preharvest Abiotic Stresses on the Accumulation of Bioactive Compounds in Horticultural Produce. Front. Plant Sci. 10:1212. 